\title{
MENJAGA SUSTAINABILITAS PENGEMBANGAN MASYARAKAT PESISIR KEBUMEN: ANTARA CORAK TOP-DOWN, PARTISIPATIF DAN INISIASI KELEMBAGAAN LOKAL
}

\author{
Waluyo Handoko, Sofa Marwah dan Tri Rini Widyastuti \\ Fakultas Ilmu Sosial dan Ilmu Politik Universitas Jenderal Soedirman \\ Email : whandoko_18@yahoo.com;
}

\begin{abstract}
ABSTRAK, Pengembangan program pemberdayaan kawasan pesisir sering mengalami kendala dalam hal ketidaksesuaian program dengan karakteristik dan kebutuhan masyarakat penerima program, sehingga peruntukkan program tidak tepat sasaran. Dalam hal ini penguatan partisipasi masyarakat pesisir sangat penting dilakukan agar program pemberdayaan selaras dengan kebutuhan masyarakat. Tulisan ini dimaksudkan untuk mengkaji aspek sustainabilitas program pengembangan masyarakat pesisir Kebumen, yaitu PKPT (Pengembangan Kawasan Pesisir Tangguh) yang bersifat top-down, partisipatif dan menginisiasi lahirnya kelembagaan lokal. Penelitian ini menggunakan metode kualitatif dengan sasaran penelitian Kelompok Masyarakat Pesisir Desa Jogosimo dan Tegalretno sebagai penerima PKPT, pemerintah desa, Dinas Kelautan dan Perikanan Kebumen, masyarakat dan sebagainya. Hasil penelitian menunjukkan bahwa PKPT yang memiliki semangat pemberdayaan dengan mengkombinasikan top-down dan bottom$u p$, ternyata masih diliputi oleh corak top-down yang cukup kuat. PKPT yang bersifat partisipatif awalnya, memberi harapan bagi keberlanjutan program pengembangan yang bukan project semata. Sayangnya ruang bottom-up yang ada direduksi oleh kontrol pengambil kebijakan. Selain itu, keberadaan KMP sebagai pengelola PKPT menyiratkan bentukan dari atas semata serta menambah keragaman berbagai kelompok masyarakat yang sudah terlebih dahulu ada. Banyaknya kelompok masyarakat tersebut justru memberi ruang bagi dominasi elit yang sudah lama berkecimpung di berbagai kelembagaan fungsional desa. Kesimpulan studi ini menekankan pentingnya memperluas ruang bagi corak bottom-up dalam program pengembangan mendatang serta melakukan penguatan kelompok masyarakat pesisir yang sudah ada sebagai upaya menjaga aspek keberlanjutan program pengembangan tersebut.
\end{abstract}

Kata kunci: pengembangan, masyarakat pesisir, top-down, partisipatif

\section{PRESERVE THE SUSTAINABILTY OF KEBUMEN COMMUNITY DEVELOPMENT: BETWEEN TOP-DOWN FEATURE, PARTICIPATION AND LOCAL INSTITUTIONAL INITIATION}

\begin{abstract}
The development of coastal empowerment program often faces constraints in terms of non-conformity of the program with the characteristics and needs of the beneficiary community, thus the allocation of the program is not on target. In this case the strengthening of the participation in coastal communities is very important to do so that the empowerment programs are in harmony with the needs of the community. This paper is intended to examine the aspects of sustainability of the development program of coastal communities in Kebumen, which is PKPT (Pengembangan Kawasan Pesisir Tangguh = The Development of Resilient Coastal Areas) with top-down characteristic, participatory, and initiating the emerging of local institutions. This research used qualitative method by choosing research location in Jogosimo and Tegalretno villages as recipients of PKPT program, village government, Maritime and Fishery Department of Kebumen, society and so on The research result showed that PKPT with the spirit of empowerment by combining top-down and bottom-up was still covered by a strong top-down feature. The PKPT that was initially participative gave confidence to sustain the development programs that were not the project alone. Unfortunately, the existing bottom-up space was reduced by the control of policy-maker. In addition, the existence of the Coastal Communities Group (Kelompok Masyarakat Pesisir = KMP) as a manager of PKPT implied the formation of the above and increased the diversity of various community groups that have been already there first. The large number of community groups provided space for elite domination that has long involved in various functional institutions of the village. The conclusions of this study emphasize the importance of widening the space for bottom-up features in future development programs and strengthening existing coastal communities as an effort to maintain the sustainability aspects of the development program.
\end{abstract}

Key words: development, coastal communities, top-down, participative

\section{PENDAHULUAN}

Seperti diketahui wilayah Indonesia didominasi wilayah pesisir dengan laut seluas 5,8 juta $\mathrm{km}^{2}$ dengan garis pantai sepanjang $81.000 \mathrm{~km}$. Dalam hal ini, lebih dari 140 juta penduduk Indonesia (60\%) tinggal di wilayah pesisir dan $80 \%$ di antaranya bergantung pada pemanfaatan sumber daya perikanan kelautan. Dalam pengelolaan pesisir, Orde Baru menerapkan kebijakan yang bersifat sentralistik dengan menempatkan peran negara sebagai figur sentral untuk mengembangkan pesisir di Indonesia. Orde Baru senantiasa mengusung jargon modernisasi dalam membangun kawasan pesisir. Kebijakan Orde Baru bersifat top-down yang kurang mampu menjawab persoalan masyarakat pesisir yang beragam dan khas. Dampak yang ditimbulkannya kurang dapat menghapus kesenjangan sosial ekonomi masyarakat pesisir ataupun potensi konflik horizontal dalam interaksi sosial masyarakat pesisir. Contoh kebijakan Orde Baru yang bersifat top-down adalah program motorisasi pada era 1980an, yaitu pengadaan perahu motor untuk nelayan yang diharapkan dapat 
meningkatkan produktifitas penangkapan ikan. Namun demikian kebijakan motorisasi armada ini banyak mengalami kegagalan yang disebabkan oleh penetapan sasaran yang tidak tepat, justru dapat berseberangan dengan nelayan kecil, dimanfaatkan oleh elit atau aparat untuk kepentingan pribadi atau kelompok dan menyingkirkan kepentingan umum para nelayan (Nikijuluw, Victor PH, 2010 :16).

Seiring dengan arus perubahan pada era reformasi, kebijakan pemerintah pusat mengalami perubahan dengan mengkreasikan kebijakan yang bersifat top-down dan bottom-up menyusun perencanaan pembangunan daerah (Satries, 2014: 91). Dengan kata lain, pemerintah telah mengembangkan kebijakan pembangunan yang tidak lagi melulu bersifat top-down namun juga mendorong corak yang bottom-up. Beberapa contoh program pembangunan dengan mengusung jargon bottom-up yang terkait dengan pengembangan daerah pesisir adalah program Pemberdayaan Ekonomi Masyarakat Pesisir (PEMP) dan Program Pengembangan Pesisir Tangguh (PKPT).

Pengelolaan wilayah pesisir menjadi salah satu sasaran Pemerintahan Presiden Joko Widodo yang memiliki visi "Terwujudnya Indonesia yang berdaulat, mandiri dan berkepribadian berlandaskan gotong royong." Adapun salah satu misi pemerintahannya adalah mewujudkan Indonesia menjadi negara maritim yang mandiri, maju, kuat, dan berbasis kepentingan nasional. PKPT adalah salah satu bentuk implementasi dari upaya pencapaian misi nasional tersebut. PKPT merupakan kelanjutan dari kebijakan pemerintah tentang Pengembangan Desa Pesisir Tangguh (PDPT) yang telah dijalankan oleh Kementrian Kelautan dan Perikanan (KKP) pada 2012-2014. Seiring dengan lahirnya UU No.6 Tahun 2014 tentang Desa, PDPT berubah menjadi PKPT. Berdasarkan evaluasi dari KKP, PDPT dinilai telah menghasilkan tranformasi sosial ekonomi berupa alternatif peningkatan ekonomi masyarakat melalui usaha yang ramah lingkungan, perbaikan infrastruktur di tingkat desa, menguatnya budaya gotong royong dan sebagainya (Pedoman Teknis PKPT 2015, 2015 : 1). Kurang berhasilnya program pengembangan di masa lalu terkait corak program yang bersifat top-down sehingga mengabaikan nilai-nilai dan karakteristik lokal serta lemahnya keterlibatan aktif masyarakat dalam perencanaan dan implementasi program tampaknya menjadi pelajaran penting bagi PDPT.

Kawasan pesisir Kebumen menjadi salah satu sasaran program PKPT pada periode 2015-2017. Dalam hal ini terdapat tiga desa pesisir, yaitu Desa Jogosimo dan Tanggulangin Kecamatan Klirong, serta Desa Tegalretno Kecamatan Petanahan yang ditetapkan sebagai penerima PKPT periode 2015-2017. Penetapan tersebut berdasarkan Keputusan Bupati Kebumen No. 523/358/Kep/2015 tanggal 7 April 2015 tentang Lokasi Kegiatan Pengembangan Kawasan Pesisir Tangguh
(PKPT) Kabupaten Kebumen Tahun 2015. Ketiga desa tersebut memenuhi lima kriteria sebagai sasaran program PKPT, yaitu: 1) lokasi rawan bencana dan perubahan iklim; 2) mempunyai potensi lokal unggulan; 3) masyarakat pesisir miskin namun potensial aktif dan memiliki motivasi memperbaiki kehidupannya; 4) kondisi pemukiman kumuh; dan 5) terjadi degradasi lingkungan (Profil Kawasan Pesisir Kebumen, 2015: 14).

Seiring dengan pemberlakuan PKPT di pesisir Kebumen, kajian mengenai dinamika program pengembangan yang bersifat top-down dan bottom-up tentu merupakan hal yang menarik untuk diteliti. Perlu dipahami, bahwa masyarakat pesisir Kebumen seperti halnya banyak daerah lain di Indonesia, masih banyak yang hidup dalam kemiskinan. Semula masyarakat pesisir sudah terbiasa dengan model pengembangan yang kurang mengikutsertakan keaktifan masyarakat seiring penetrasi kebijakan sentralistik Orde Baru. Selain itu, keberadaan elit-elit yang biasa terlibat dalam pengambilan kebijakan di tingkat desa, baik elit formal maupun informal, ketika program pengembangan menuntut arus aspirasi dari tingkat bawah, cenderung menimbulkan gesekan politik yang menarik untuk diteliti lebih lanjut. Satu hal lain yang penting pula adalah apakah program pengembangan yang bersifat top-down dan bottom-up juga memiliki orientasi untuk menjaga sustainabilitas program, mengingat pada masa lalu banyak program top-down yang tidak berkelanjutan.

Dengan demikian, menjadi hal yang urgen untuk melakukan studi evaluasi dalam rangka menjaga keberlangsungan program, khususnya dalam konteks program yang mempunyai corak kombinasi top-down dan bottom-up bagi masyarakat pesisir. Selain itu urgensitas lainnya adalah penerapan program tersebut dilakukan pada masyarakat yang selama ini terbiasa dengan kebijakan top-down. Adanya kombinasi kebijakan yang bersifat top-down dan bottom-up serta implementasi kebijakan dalam masyarakat pesisir yang sudah terbiasa dengan mekanisme kebijakan yang bersifat top-down menunjukkan adanya permasalahan penelitian yang menarik dan penting untuk dikaji. Apalagi tarik ulur kedua corak kebijakan tersebut juga diwarnai oleh keberadaan elit desa, baik formal dan nonformal yang terbiasa mendominasi dalam pengambilan keputusan di desa. Dengan demikian maka rumusan masalah dalam penelitian ini adalah bagaimanakah dinamika tarik ulur antara partisipasi masyarakat dan pemberlakuan kebijakan top-down berupa pedoman teknis program PKPT, serta bagaimanakah strategi untuk menjaga sustainabilitas program melalui penguatan kelembagaan lokal.

Berdasarkan rumuan masalah tersebut maka tujuan tulisan ini adalah untuk mengkaji dinamika tarik ulur program pengembangan yang di satu sisi mencoba memberikan ruang partisipatif bagi masyarakat, namun di sisi lain masih dibekali dengan berbagai 
ketentuan dan pedoman teknis yang harus diikuti serta inisiasi penguatan kelembagaan lokal untuk menjaga sustainabilitas program pengembangan ke depan. Kondisi demikian berlangsung di tengah peran elit-elit yang terlibat dalam perencanaan maupun implementasi PKPT di tingkat desa. Kajian demikian penting untuk mendukung agar sustainabilitas program pengembangan pesisir tidak lagi berhenti tatkala project sudah selesai. Terlebih program pengembangan pesisir saat ini juga bersinggungan dengan tuntutan UU No.6 Tahun 2014 tentang Desa, yaitu melahirkan lembaga Badan Usaha Unit Desa (BUMDes).

\section{METODE}

Penelitian ini menggunakan metode penelitian kualitatif agar tujuan penelitian yang ditetapkan dapat dicapai karena sifat penelitian kualitatif yang dapat mengkonstruksikan fenomena secara lebih detail (Strauss dan Corbin, 1990). Lokasi penelitian di Kabupaten Kebumen dengan memilih situs penelitian Desa Jogosimo (Kecamatan Klirong) dan Desa Tegalretno (Kecamatan Petanahan). Penentuan informan berdasarkan kriteria yang dibutuhkan penelitian ini, yaitu pengelola PKPT Desa Jogosimo dan Tegalretno atau Kelompok Masyarakat Pesisir (KMP), Kepala Desa Jogosimo dan Kepala Desa Tegalretno, masyarakat penerima program, tokoh masyarakat, Kepala Dinas Dinas Kelautan dan Perikanan (Dinlutkan), dan tim pendamping PKPT. Penelitian ini menggunakan teknik pengumpulan data dengan kombinasi wawancara, FGD, studi dokumen, dan observasi. Pengolahan dan analisis data dimulai pada setiap waktu pada pengumpulan data secara simultan, yang diawali dengan proses klarifikasi data, dilanjutkan dengan abstraksi teoritis terhadap informasi dan fakta di lapangan untuk menghasilkan pernyataan-pernyataan yang mendasar dan kemudian menarik simpulan.

\section{HASIL DAN PEMBAHASAN}

\section{Profil Masyarakat Pesisir Kebumen}

Wilayah pesisir Kebumen terbentang sepanjang 57,5 kilometer di wilayah pesisir selatan Pulau Jawa. Wilayah pantai selatan mendukung sektor perikanan, dataran rendah yang subur mendukung sektor pertanian, sementara kawasan perbukitan untuk sektor perkebunan dan hutan. Kondisi tersebut memperlihatkan keragaman pekerjaan warga tidak hanya menjadi nelayan, tetapi juga menjadi petani, peternak dan berkebun. Pesisir Kebumen meliputi delapan kecamatan, yakni Kecamatan Mirit, Ambal, Buluspesantren, Klirong, Petanahan, Puring, Buayan, dan Ayah. Wilayah pesisir Kebumen memiliki potensi berupa perikanan tangkap, perikanan budidaya, wisata bahari, ekowisata, wisata kuliner, dan kawasan monopolitan (Profil Kawasan Pesisir Kebumen, 2015:1421).
Lokasi penelitian ini, yaitu di Kecamatan Klirong dan Petanahan. Kecamatan Klirong memiliki batas wilayah sebelah timur Kecamatan Buluspesantren, sebelah utara Kecamatan Pejagoan, sebelah barat Kecamatan Petanahan, dan sebelah selatan Samudera Indonesia. Desa Jogosimo berjarak $7 \mathrm{~km}$ arah selatan dari ibukota Kecamatan Klirong dan $20 \mathrm{~km}$ arah barat daya dari ibu kota kabupaten. Jumlah penduduk Desa Jogosimo sebanyak 2.852 jiwa, terdiri dari 1.475 jiwa atau 51,7 persen laki-laki dan 1.377 jiwa atau 48,3 persen perempuan. Adapun Kecamatan Petanahan terletak di wilayah pesisir dengan batas sebelah utara, yaitu Kecamatan Sruweng dan Adimulyo, sebelah timur Kecamatan Klirong, sebelah selatan Kecamatan Puring, dan sebelah barat Samudera Indonesia. Desa Tegalretno, berjarak $8 \mathrm{~km}$ arah selatan dari ibukota kecamatan dan 24 kilometer arah barat daya dari ibu kota kabupaten. Jumlah penduduk Desa Tegalretno sebanyak 1853 jiwa, terdiri dari laki-laki sebanyak 984 jiwa (53,2 persen), dan perempuan sebanyak 869 jiwa (46,8 persen) (Profil Kawasan Pesisir Kebumen, 2015 :16).

Aktivitas ekonomi masyarakat Desa Jogosimo dan Tegalretno mengandalkan kondisi kawasan pesisir yang meliputi wilayah kelautan dan lahan kering. Dalam hal ini warga kedua desa pesisir tersebut selain menjadi nelayan, sebagian besar dari mereka memiliki mata pencaharian sebagai petani, peternak, atau petani kebun. Selain itu, warga setempat juga mengembangkan industri rumah tangga seperti kerajinan keset, anyaman bambu, penghasil gula kelapa, dan tentu saja membuat produk olahan dari ikan. Di Desa Jogosimo terdapat 211 unit usaha yang menyerap 414 tenaga kerja, dan di Desa Tegalretno mempunyai 246 unit usaha yang menyerap 457 tenaga kerja (Profil Kawasan Pesisir Kebumen, $2015: 19)$

\section{Implementasi PKPT di Tengah Tarik Ulur Corak Top-Down dan Bottom-Up}

PKPT merupakan kelanjutan dari program Pengembangan Desa Pesisir Tangguh (PDPT) yang telah dijalankan oleh KKP pada periode 2012-2014. Program PDPT telah dilaksanakan di 66 desa pesisir di 22 kabupaten di seluruh Indonesia dalam tiga tahun terakhir. Program PDPT bertujuan meningkatkan keterpaduan pembangunan pesisir pada level kegiatan desa, kelurahan, atau lokasi yang terletak pada satu hamparan. Sejauh ini menurut informasi Direktorat Pesisir dan Kelautan kegiatan PDPT telah terbukti dapat meningkatkan ketangguhan desa-desa pesisir yang menjadi sasaran PDPT (Pedoman Teknis PKPT 2015, 2015 : 1).

Pada prinsipnya, program PKPT tetap melakukan pendekatan top-down dengan memperhatikan perencanaan yang dibuat oleh pemerintah kabupaten/kota, seperti Rencana Tata Ruang Wilayah (RTRW), Rencana Pembangunan Jangka Menengah Daerah (RPJMD), Rencana Strategis Wilayah Pesisir dan Pulau-Pulau 
Kecil, dan sebagainya. Selain itu, KKP juga menetapkan Peraturan Dirjen Kelautan, Pesisir dan Pulau-pulau kecil No/PER-DJKP3K/2015 tentang Pedoman Teknis Pengembangan Kawasan Pesisir Tangguh 2015. Namun juga PKPT melakukan pendekatan bottom-up melalui penyusunan Rencana Pengembangan Kawasan Pesisir (RPKP) dalam bentuk dokumen berisikan rancangan kerja masyarakat pesisir untuk jangka waktu lima tahun ke depan melalui participation rural appraisal (PRA) serta focused group discussion (FGD). Dalam hal ini penyusunan program dalam RPKP memperhatikan perencanaan dalam RPJMDEs, dan sebaliknya RPJMDes yang disusun nantinya juga menggunakan masukan dari RPKP.

Kelahiran program pemberdayaan semacam PKPT pada tahun 2015 sesungguhnya mencerminkan upaya untuk memberikan kewenangan, tanggung jawab, dan kesempatan pada masyarakat pesisir untuk mengelola sumber daya alam perikanan dengan terlebih dahulu mendefinisikan kebutuhan, keinginan, tujuan dan aspirasi masyarakat. Diharapkan dengan adanya kebijakan yang menggabungkan antara top-down, dan bottom-up dapat mendorong kemampuan partisipatif masyarakat dalam mengelola sumber daya secara terpadu, mendorong kesadaran masyarakat tentang pentingnya keberlanjutan sumber daya alam, serta meningkatkan kesejahteraan masyarakat dengan tetap menjamin adanya kelestarian dan keberlanjutan ekologi. Hal tersebut dapat diamati dalam tahapan PKPT, yaitu semangat partisipatif dengan adanya keterlibatan masyarakat pada tahapan yang dilalui, terutama dalam penyusunan RPKP yang disusun mengacu pada profil kawasan dan rencana masyarakat berdasarkan masukan masyarakat hasil participation rural appraisal dan diskusi kelompok FGD.

Sesungguhnya model kombinasi seperti ini telah memberikan ruang untuk proses dialogis dengan masyarakat melalui musyawarah ataupun konsultasi publik. Sayangnya posisi penentu akhir tetap didominasi oleh pemerintah. Dalam konteks pelaksanaan PKPT wilayah pesisir Kebumen, penyusunan RPKP di Desa Jogosimo dan Tegalretno dilakukan oleh tim penyusun program PKPT yang dibentuk kepala desa bersama Kelompok Masyarakat Pesisir (KMP) melalui FGD dan difasilitasi oleh Dinas Kelautan dan Perikanan (Dinlutkan) dan dipandu tim pendamping. KMP adalah pengelola PKPT di tingkat desa yang bertanggungjawab pada pelaksanaan PKPT. Adapun pemilihan program kegiatan lebih banyak mengacu pada RPJMDes terakhir. Pada akhirnya program dalam RPKP adalah program yang telah masuk dalam RPJMDes dan harus menyesuaikan dengan pedoman teknis PKPT dari KKP. Bahkan pedoman teknis menjadi basis pengambilan keputusan.

Meskipun label yang diusung PKPT bersifat mengkombinasikan top-down dan bottom-up, namun dalam praktiknya desain program pembangunan yang muncul tetap bercorak kekuatan pemerintah yang tercermin dari eksistensi pedoman teknis sebagai penentu akhir program yang didanai. Sejauh ini kebijakan pembangunan top-down dianggap menimbulkan banyak persoalan seperti program tidak berkelanjutan dan kurang sesuai dengan kebutuhan lokal masyarakat. Dalam konteks demikian, studi yang dilakukan oleh Djoeffan (2002 : 75) misalnya, menyimpulkan pentingnya strategi penguatan partisipasi masyarakat dalam perencanaan pembangunan. Adapun studi oleh Puspitaarum (2007: 65) menunjukkan mekanisme top-down dan bottomup sebagai bentuk-bentuk perencanaan pembangunan di wilayah perdesaan atau kelurahan (Puspitaarum, 2017:65). Tentu saja pembangunan yang bersifat topdown tetap dibutuhkan, khususnya bagi isu pembangunan yang vital dan menyangkut kepentingan masyarakat luas atau menyangkut pelayanan antar wilayah, seperti halnya sarana transportasi ataupun fasilitas umum perikanan. Namun demikian, pembangunan yang memperluas corak partisipatif atau bottom-up menjadi salah satu pilihan penting dalam perencanaan pembangunan khususnya di wilayah perdesaan khususnya pesisir.

Pembangunan perdesaan memiliki makna membangun masyarakat perdesaan dengan menempatkan kebutuhan masyarakat sebagai hal yang utama. Untuk kebutuhan yang berkaitan dengan pengembangan masyarakat secara langsung, seperti halnya bina usaha ekonomi masyarakat cenderung lebih tepat dengan pendekatan bottom-up. Hal tersebut berseberangan dengan pelaksanaan PKPT, karena ketersediaan Pedoman Teknis PKPT telah diperluas menjadi pedoman akhir yang membatasi kreativitas masyarakat sehingga mencerminkan kebijakan top-down yang cukup kuat. Pedoman teknis bukanlah semata-mata memuat garis besar panduan program PKPT belaka, namun penyerapan aspirasi masyarakat pada proses penyusunan RPKP justru dengan mudah tersingkir apabila dianggap tidak sesuai pedoman teknis. Dalam tataran ini, upaya partisipatif pada akhirnya dimentahkan oleh intervensi pemerintah melalui kekuatan pedoman teknis yang dibentuk.

Dalam corak kebijakan top-down sekaligus bottom-up demikian itu, terdapat pergulatan berbagai elit kebijakan yang terlibat dalam memaknai perumusan program kegiatan ataupun implementasinya. Dalam hal ini keberadaan elit pemerintah sebenarnya telah diseimbangkan dengan wacana pemberdayaan dan kehadiran tim pendamping yang bertindak sebagai mitra kerja pemerintah dan mendampingi KMP dalam mengelola PKPT. Sesuai dengan pedoman teknis yang diberikan oleh KKP, tim pendamping terdiri dari empat orang (minimal satu perempuan, tiga laki-laki). Meskipun tim pendamping dihadirkan dalam pelaksanaan PKPT di lapangan, namun pada saat bersamaan, melalui kewenangan yang dimilikinya, pemerintah daerah tetap memberikan batasan 
yang jelas bagi implementasi PKPT, yaitu semua program kegiatan harus mengacu pada pedoman teknis dari KKP.

Dalam satu tahun pelaksanaan, sesuai dengan penilaian dari Dinlutkan Kebumen, terjadi peningkatan nilai ketangguhan, baik di Desa Jogosimo maupun Tegalretno dalam hal aspek manusia, aspek usaha, aspek lingkungan, dan aspek siaga bencana dan perubahan iklim. Adapun untuk aspek sumber daya, tingkat ketangguhan di kedua desa tersebut belum meningkat sampai akhir 2015. Berikut selengkapnya dalam tabel.

Penilaian yang dilakukan oleh Dinlutkan bersama dengan tim pendamping memiliki kriteria dan indikator yang ketat mulai dari aspek manusia sampai siaga bencana dan perubahan iklim. Di satu sisi, keberadaan dokumen penilaian oleh Dinlutkan dan tim pendamping dapat bersifat positif karena untuk mengevaluasi seberapa jauh program PKPT selama satu tahun berdampak meningkatkan ketangguhan masyarakat pesisir. Namun di sisi lain, keberadaan dokumen ketangguhan yang disiapkan oleh Dinlutkan dan tim pendamping berdasarkan Pedoman Teknis PKPT sesungguhnya merefleksikan bagaimana mekanisme partisipatif masya-rakat diambil alih oleh pengambil kebijakan. Dalam hal ini partisipasi masyarakat untuk memahami kebutuhan mereka direduksi melalui indikator-indikator yang ditentukan oleh pemerintah setempat. Sesungguhnya dengan mekanisme demikian, masyarakat pesisir kurang memahami pada aspek mana dan bagaimana subtansi dari ketangguhan itu. Mereka kurang memahami aspek mana dari ketangguhan itu yang perlu dipertahankan atau ditingkatkan. Masyarakat bahkan kurang mengerti pemahaman mengenai makna pesisir tangguh itu.

Dalam konteks masyarakat pesisir Kebumen, kombinasi corak top-down dan bottom-up yang dalam praktiknya masih lebih berbobot sifat topdown tersebut juga menimbulkan persoalan khusus. Sesuai dengan karakteristik pesisir Kebumen yang mendukung sektor kelautan, perikanan, juga memiliki dataran rendah yang subur untuk pertanian dan peternakan, bahkan memiliki kawasan perbukitan yang mendukung perkebunan dan hutan, maka mata pencaharian masyarakat tidak hanya menjadi nelayan, namun juga petani, peternak, berkebun dan sebagainya. Dalam implementasi di Desa Jogosimo dan Tegalretno, antara masyarakat dan pengelola PKPT, tidak satu pemahaman dalam hal peruntukkan program kegiatan PKPT. Di satu sisi, kegiatan PKPT dipahami secara khusus diperuntukkan untuk kegiatan yang bersifat kelautan sesuai Pedoman Teknis PKPT, di sisi lain mata pencaharian penduduk setempat tidak semuanya mengandalkan kelautan sesuai karakteristik wilayahnya. Dalam hal ini terlihat bobot top-down lebih kuat, sehingga kegiatan lain di luar yang bersifat kelautan tidak bisa didanai oleh PKPT. Hal demikian menimbulkan kerisauan di level grassroot karena tidak memahami peruntukkan program PKPT yang sesungguhnya untuk kelompok masyarakat mana.

Tabel 1. Aspek Ketangguhan Desa Jogosimo

\begin{tabular}{|c|c|c|c|c|c|c|c|c|c|}
\hline \multirow{2}{*}{$\begin{array}{c}\text { Kriteria } \\
\text { ketangguhan }\end{array}$} & \multicolumn{2}{|c|}{$\begin{array}{c}\text { Total skor tiap } \\
\text { aspek }\end{array}$} & \multicolumn{3}{|c|}{$\begin{array}{c}\text { Kondisi ketangguhan } \\
\text { tiap aspek }(\%)\end{array}$} & \multicolumn{4}{|c|}{ Nilai ketangguhan } \\
\hline & $\mathrm{T}-0$ & $\mathrm{~T}-1$ & Ket. & $\mathrm{T}-0$ & $\mathrm{~T}-1$ & Ket. & $\mathrm{T}-0$ & $\mathrm{~T}-1$ & Ket. \\
\hline Aspek manusia & 21 & 22,5 & Naik 1,5 & 55 & 62,5 & Naik $7,5 \%$ & 11 & 12,5 & Naik 1,5 \\
\hline Aspek usaha & 20,5 & 23,5 & Naik 3,0 & 52,5 & 67,5 & Naik $15 \%$ & 10,5 & 13,5 & Naik 3,0 \\
\hline Aspek sumber daya & 19 & 19 & Tetap & 45 & 45 & Tetap & 9 & 9 & Tetap \\
\hline $\begin{array}{l}\text { Aspek lingkungan/ } \\
\text { infrastruktur }\end{array}$ & 22,5 & 23 & Naik 0,5 & 62,5 & 65 & Naik $2,5 \%$ & 12,5 & 13 & Naik 0,5 \\
\hline $\begin{array}{l}\text { Aspek siaga } \\
\text { bencana \& } \\
\text { perubahan iklim }\end{array}$ & 20,5 & 21 & Naik 0,5 & 52,5 & 55 & Naik $2,5 \%$ & 10,5 & 11 & Naik 0,5 \\
\hline Jumlah & 103,5 & 109 & Naik 5,5 & 53,5 & 59 & Naik $5,5 \%$ & 53,5 & 59 & Naik 5,5 \\
\hline
\end{tabular}

Keterangan: T0= tahun sebelum PKPT; T1= tahun pertama PKPT

Sumber : Dokumen Penilaian Ketangguhan Kawasan, Dinlutkan Kebumen, 2015: 5.

Tabel 2. Aspek Ketangguhan Desa Tegalretno

\begin{tabular}{|c|c|c|c|c|c|c|c|c|c|}
\hline \multirow{2}{*}{$\begin{array}{c}\text { Kriteria } \\
\text { ketangguhan }\end{array}$} & \multicolumn{2}{|c|}{$\begin{array}{c}\text { Total skor tiap } \\
\text { aspek }\end{array}$} & \multicolumn{4}{|c|}{$\begin{array}{l}\text { Kondisi ketangguhan } \\
\text { tiap aspek }(\%)\end{array}$} & \multicolumn{2}{|c|}{ Nilai ketangguhan } & \multirow[b]{2}{*}{ Ket. } \\
\hline & $\mathrm{T}-0$ & $\mathrm{~T}-1$ & Ket. & $\mathrm{T}-0$ & $\mathrm{~T}-1$ & Ket. & $\mathrm{T}-0$ & $\mathrm{~T}-1$ & \\
\hline Aspek manusia & 21 & 23,5 & Naik 2,5 & 55 & 67,5 & Naik 2,5\% & 11 & 13,5 & Naik 2,5 \\
\hline Aspek usaha & 16 & 22 & Naik 6,0 & 30 & 60 & Naik 30\% & 6 & 12 & Naik 6,0 \\
\hline Aspek sumber daya & 17 & 17 & Tetap & 35 & 35 & Tetap & 7 & 7 & Tetap \\
\hline $\begin{array}{l}\text { Aspek lingkungan/ } \\
\text { infrastruktur }\end{array}$ & 22,5 & 24,5 & Naik 2,0 & 62,5 & 72,5 & Naik $10 \%$ & 12,5 & 14,5 & Naik 2,0 \\
\hline $\begin{array}{l}\text { Aspek siaga } \\
\text { bencana \& } \\
\text { perubahan iklim }\end{array}$ & 19,5 & 20 & Naik 0,5 & 47,5 & 50 & Naik $2,5 \%$ & 9,5 & 10 & Naik 0,5 \\
\hline Jumlah & 96 & 107 & Naik 11 & 46 & 57 & Naik $11 \%$ & 46 & 57 & Naik 11 \\
\hline
\end{tabular}

Keterangan: $\mathrm{T} 0=$ tahun sebelum PKPT; $\mathrm{T} 1=$ tahun pertama PKPT

Sumber : Dokumen Penilaian Ketangguhan Kawasan, Dinlutkan Kebumen, 2015 : 5 
Kekhasan kawasan pesisir satu dengan yang lain seperti inilah yang sesungguhnya penting untuk dipahami dalam pengelolaan PKPT yang dari awal sebenarnya memiliki semangat partisipatif yang cukup kuat. Untuk itu menjadi penting menambah atau memperluas bobot corak bottom-up sehingga PKPT dapat lebih sesuai dengan karakteristik lokal dan dapat bermanfaat bagi kebutuhan masyarakat pesisir yang sesungguhnya. Sejalan dengan temuan studi tersebut, misalnya studi dari Siti Aminah (2010) yang menegaskan pentingnya pelaksanaan program pemberdayaan nelayan yang berbasis keunikan dan kelembagaan lokal dalam program pemberdayaan di kawasan pesisir Tangerang; Demikian pula studi yang dilakukan oleh Juniarta (2013 : 19), yang melakukan penelitian di kawasan pesisir Sumberasih Probolinggo, menyimpulkan bahwa dalam pemberdayaan masyarakat pesisir penting untuk mengakomodasi nilai-nilai kearifan lokal sebagai bentuk penerapan community based management.

Jika mencermati mekanisme penyusunan program PKPT dan pelaksanaannya, upaya untuk memperluas ruang bottom-up, yaitu dengan memberikan kelonggaran untuk menentukan program kegiatan yang semata-mata berbasis pada kebutuhan masyarakat. Hal ini menjadi penting mengingat masyarakat menjadi pihak yang paling mengetahui keinginan dan kebutuhannya. Terlebih masyarakat pesisir Kebumen memiliki keragaman dalam corak mata pencahariannya sehingga program kegiatan PKPT seharusnya lebih mencerminkan kesesuaian dengan karakteristik masyarakat. Tentunya dengan adanya keragaman karakteristik demikian akan menjadi terlalu sederhana bila harus direduksi dengan ketentuan pedoman teknis semata. Pedoman teknis seharusnya hanya berisikan garis-garis besar dalam implementasi PKPT. Demikian pula dalam pengisian keanggotaan KMP lebih banyak mendengarkan kepentingan pengambil kebijakan. Mereka yang ditunjuk sebagai pengelola KMP lebih merepresentasikan kepentingan pengambil kebijakan, karena para pengambil kebijakan memilih mereka dengan pertimbangan pernah mengelola program pemberdayaan sebelumnya dan kurang memberi kesempatan bagi tokoh-tokoh baru di masyarakat untuk berperan serta. Untuk itu, mendengarkan harapan warga memilih sendiri pengelola KMP yang diinginkan dan memberikan kesempatan yang sama bagi warga untuk berkecimpung mengelola PKPT menjadi alternatif yang patut dipertimbangkan.

Dengan demikian, kebijakan yang mengkombinasikan corak top-down sesungguhnya dapat menjadi kelebihan dalam hal pengaturan yang jelas berupa garis-garis besar dalam hal implementasi program pengembangan seperti PKPT. Hal ini penting untuk menjadi masukan para pengambil kebijakan khususnya Dinlutkan dan hierarkhinya ke atas. Namun demikian, para pengambil kebijakan juga perlu paham bahwa karakteristik wilayah pesisir adalah beragam dan bersifat khas. Seperti halnya kawasan pesisir Kebumen yang tidak selalu mengandalkan kelautan sebagai sumber pangan, maka penting bagi program pengembangan selanjutnya untuk memperhatikan kondisi karakteristik tersebut. Kenyataannya, masyarakat pesisir bukan hanya nelayan, tapi juga petani, pedagang, peternak dan sebagainya. Demikianlah pula penting untuk menjadi masukan bagi pengambil kebijakan bahwa pengelolaan program tersebut sebaiknya justru tidak memberi peluang bagi dominasi tokoh-tokoh lama untuk melaksanakan program, sehingga partisipasi masyarakat secara lebih luas dapat terus meningkat.

\section{Menjaga Aspek Sustainabilitas : Penguatan Kelembagaan Lokal}

Sebagai program pengembangan, PKPT diharapkan dapat mengatasi berbagai persoalan yang dihadapi masyarakat pesisir sekaligus memanfaatkan potensi sumber daya yang ada secara optimal. Untuk mencapai hal tersebut, diperlukan instrumen kelembagaan yang diharapkan berperan sebagai penggerak pemanfaatan potensi-potensi di wilayah pesisir. Dalam hal ini, Kelompok Masyarakat Pesisir (KMP) dibentuk dalam kerangka PKPT yang bertindak sebagai pengelola PKPT dan bertanggung jawab terhadap pelaksanaan PKPT. Sesuai dengan persyaratan dalam Pedoman Teknis PKPT dari KKP, anggota KMP berjumlah empat sampai dengan tujuh orang. Dalam hal ini keanggotan KMP di masingmasing desa sebanyak empat orang mewakili unsur Karangtaruna, BPD, perempuan, dan tokoh masyarakat. Adapun nama KMP Desa Jogosimo adalah KMP Pedang Laut dan KMP Desa Tegalretno bernama KMP Margi Rahayu.

Pedoman Teknis Pengembangan Kawasan Pesisir Tangguh (PKPT) yang dikeluarkan oleh KKP mengatur secara lengkap pedoman teknis mulai dari model pengembangan PKPT, kriteria lokasi, jenis kegiatan, sampai dengan pemilihan anggota KMP sebagai pengelola PKPT di tingkat desa. Namun demikian, para pengambil kebijakan kurang sensitif untuk memahami kondisi dari sudut pandang kebutuhan masyarakat grassroot. Hal tersebut dikarenakan KMP bekerja mengelola PKPT tanpa menerima gaji karena dalam penganggaran memang tidak ada, sehingga menimbulkan protes dan menjadi ironi mengingat taraf kehidupan warga yang miskin. Selain itu, secara teknis kurang ada mekanisme untuk mengelola instruksi yang bersifat top-down dalam pengelolaan PKPT. Pemilihan anggota KMP hanya didasarkan pengalaman pada saat mengelola program pemberdayaan yang pernah ada, seperti PNPM (Program Nasional Pemberdayaan Masyarakat). Padahal tata aturan project memiliki ketentuan yang berbeda-beda. Kenyataannya, dalam bekerja KMP tidak mendapatkan pelatihan khusus dalam pengelolaan PKPT sehingga KMP tidak dapat mengerti hal-hal tertentu misalnya, status kepemilikan sarana dan pengelolaan laba dari aset PKPT. Dalam hal 
ini pembentukan KMP lebih merupakan tuntutan agar project tersebut dapat dilaksanakan sesuai pedoman teknis yang diberikan oleh KKP.

PKPT di Desa Jogosimo dan Tegalretno dilaksanakan antara tahun 2015-2017. Sebelum pelaksanaan PKPT, masyarakat Desa Jogosimo dan Tegalretno sudah memiliki banyak kelompok atau lembaga fungsional berbasis sosial ekonomi. Dalam hal ini terdapat pokdakan (kelompok pembudidaya ikan), yaitu kelompok pembudidayaan ikan yang terorganisir. Di Desa Jogosimo ada Pokdakan Mina Jaya dan Simo Fish. Adapun di Desa Tegalretno terdapat Pokdakan Manunggal Jaya. Selain keberadaan Pokdakan, terdapat pula Pohlasar atau kelompok pengolah pemasaran, yaitu kelompok pengolah dan pemasaran hasil perikanan yang melakukan kegiatan ekonomi bersama dalam wadah kelompok. Di Desa Jogosimo terdapat Pohlasar Mino Rini Putri, dan di Desa Tegalretno terdapat Pohlasar Sumber Rejeki dan Mekarsari. Di samping Pokdakan dan Pohlasar, masih terdapat Kelompok Usaha Bersama (KUB), yaitu badan usaha non badan hukum yang berupa kelompok yang dibentuk oleh nelayan berdasarkan hasil kesepakatan/musyawarah seluruh anggota yang dilandasi oleh keinginan bersama untuk berusaha bersama dan dipertanggungjawabkan secara bersama guna meningkatkan pendapatan anggota. Dalam hal ini di Desa Jogosimo terdapat KUB Mino Rini dan KUB Mino Rizki, sedangkan di Tegalretno terdapat KUB Nelayan Mina Barokah, KUB Barokah Putra, dan KUB Barokah Utama.

Keberadaan kelompok-kelompok di atas tidak lepas dari peranan Dinlutkan Kebumen yang memfasilitasi terbentuknya kelompok tersebut. Inisiasi pembentukan kelompok-kelompok nelayan tersebut seolah mencerminkan bahwa kebutuhan untuk melahirkan kekuatan masyarakat pesisir adalah sesuatu yang datang dari atas. Masyarakat dalam posisi yang kurang memahami argumen mendasar lahirnya berbagai macam kelompok tersebut. Keberadaan kelompokkelompok tersebut memiliki fungsi untuk meningkatkan pembudidayaan, pengolahan dan pemasaran ikan mungkin menjadi cara untuk mendorong kesejahteraan masyarakat pesisir secara bersama-sama. Dalam konteks masyarakat pesisir di Desa Jogosimo dan Tegalretno, keberadaan berbagai kelompok masyarakat tersebut justru membuka peluang bagi dominasi elit tertentu. Hal itu dapat terjadi karena pembentukan kelompok masyarakat tidak lepas dari peran para pengambil kebijakan di tingkat desa. Dalam hal ini elit-elit tertentu justru mengukuhkan keinginannya melalui proses dan kinerja kelompok-kelompok tersebut. Mereka yang menduduki posisi utama dalam berbagai kelompok itu, cenderung orang-orang yang sama. Demikian pula dalam konteks keberadaan KMP sebagai pengelola PKPT, terdapat kecenderungan elit mendesakkan program kegiatan tertentu sesuai kepentingan pribadi dan kurang sesuai dengan karakteristik dan kebutuhan masyarakat. Dengan demikian pola pelaksanaan PKPT yang terbentuk di lapangan membuka ruang bagi munculnya kepentingan orang-orang lama di desa. Keikutsertaan mereka dalam PKPT justru menjadi ruang mereka untuk mencapai kepentingannya sendiri.

Kondisi di atas tentunya memprihatinkan terkait dengan aspek sustainabilitas program pengembangan. Tulisan ini mengasumsikan bahwa kekuatan kelompok masyarakat akan mendukung penguatan pengembangan masyarakat ke depan. Pemanfaatan dan penguatan kelompok yang sudah ada mungkin menjadi alternatif untuk mendukung efektivitas dan keberlanjutan program pengembangan masyarakat ke depan. Berkaitan dengan penguatan kelompok masyarakat, kajian dari Afifi dan Latifah (2011: 263) menunjukkan bahwa penguatan kelembagaan perdesaan akan mendorong lahirnya partisipasi, efektivitas, efisiensi bagi pengembangan sumber daya demi mendukung pembangunan perdesaan. Jika menilik dari upaya yang dilakukan oleh PKPT sesungguhnya juga mengarah pada upaya sustainabilitas, misalnya adanya kegiatan bina kelembagaan dan penguatan kelembagaan pesisir melalui BUMdes (Pedoman Teknis Pengembangan Kawasan Pesisir Tangguh, 2015 : 35). Namun demikian, keragaman kelompok masyarakat yang sudah ada ataupun dominasi elit dalam mengelola beberapa kelompok yang ada, penting untuk diperhatikan oleh pengambil kebijakan di tingkat atas, sehingga PKPT dapat lebih mendorong penguatan kelompok yang sudah ada dan mendukung sustainabilitas program pengembangan masyarakat ke depan.

Dengan melihat kondisi tersebut, sesungguhnya KMP memiliki peranan yang sangat krusial dalam menjaga keberlanjutan program pengembangan setelah keberadaan PKPT sebagai project selesai. Penguatan KMP secara kelembagaan, di mana KMP dibentuk dan tumbuh dari kebutuhan masyarakat sendiri sangat penting demi menjaga aspek sustainabilitas. Idealnya KMP atau kelompok masyarakat sejenisnya lahir tidak sematamata kebutuhan praktis project, tapi karena masyarakat sadar mereka membutuhkan kekuatan kelompok untuk maju bersama-sama. Kondisi demikian juga akan mengeliminasi dari awal kemungkinan kepentingan sepihak elit-elit tertentu. Harapannya KMP maupun kelompok masyarakat sejenisnya dapat menjaga aspek sustainabilitas program pengembangan yang ada. Bukan hanya PKPT tentunya, tetapi program-program pengembangan selanjutnya. Di tingkatan pengambil kebijakan, meninjau kembali model kebijakan top-down dan bottom-up sangat penting untuk dapat memberikan ruang yang lebih leluasa bagi masyarakat grassroot dalam mendefinisikan kebutuhan, keinginan, tujuan dan aspirasi masyarakat lokal.

Selanjutnya terkait dengan out-put PKPT dalam tahun terakhir pelaksanaan, yaitu terbentuknya BUMDes. Seperti diketahui bahwa Pasal 87-88 dalam UU No.6 
Tahun 2014 tentang Desa menetapkan bahwa desa dapat membentuk BUMDes yang disahkan melalui Perdes. Hal itu menegaskan bahwa pemerintah desa memiliki otoritas dalam pendirian BUMDes. Oleh karena ketentuan exit strategy PKPT untuk mendirikan BUMDes memiliki dua celah. Pertama, secara subtansi upaya untuk membentuk BUMDes dalam program PKPT sejalan dengan ketentuan UU No.6 Tahun 2014 tentang Desa; Kedua, KMP sebagai pengelola PKPT tidak memiliki otoritas untuk mendirikan BUMDes karena pendirian BUMDes adalah otoritas pemerintah desa. Terkait dengan hal itu sesungguhnya KMP sebagai pengelola PKPT dapat merekomendasikan pembentukan BUMDes kepada pemerintah desa berdasarkan kebutuhan untuk menjaga sustainabilitas program PKPT, sehingga program pengembangan ke depan dapat diwadahi dalam BUMDes. Seperti diketahui bahwa pedoman teknis PKPT menuntut pembentukan BUMDes, namun sesungguhnya KMP sebagai pengelola PKPT tidak memiliki otoritas membentuk. Selain itu program kegiatan yang sudah dilaksanakan oleh warga masyarakat Desa Jogosimo dan Tegalretno seperti halnya pelatihan dan bina usaha ikan tawar, pengolahan ikan, gula semut, nata de coco, keberlanjutannya nanti dapat dikelola dan dikembangkan oleh BUMDES yang terbentuk. Keberadaan bina usaha-bina usaha tersebut dapat menjadi bagian dari unit-unit usaha yang dikelola BUMDes.

Selain itu, permasalahan lainnya adalah keberadaan BUMDes secara otoritas kewenangan di bawah koordinasi Badan Pemberdayaan Masyarakat Desa (Bapermades) bukan oleh Dinlutkan. Padahal ketika kita berbicara PKPT, maka leading sector adalah Dinlutkan. Tentu saja hal yang bersifat lintas sektoral akan membingungkan jika tidak ada keterlibatan instansi pemerintah lainnya yang terlibat dalam PKPT. Dalam operasionalisasi di tingkat kabupaten, PKPT didukung oleh Tim Teknis sembilan orang, yang terdiri dari Sekda, Dinlutkan, Bappeda, Dinas pekerjaan umum, Badan Penanggulangan Bencana, dan sebagainya. Untuk itu, sangat penting bagi Bapermades untuk terlibat dari awal operasionalisasi PKPT di tingkat kabupaten, dikarenakan exit strategy bagi PKPT adalah fokus pada pembentukan kelembagaan kawasan pesisir yaitu BUMDes. Bapermades adalah badan yang memiliki kewenangan dalam koordinasi BUMDes. Dengan adanya sinkronisasi dua instasi pemerintah tersebut, pendirian BUMDes diharapkan dapat benar-benar menjalankan usaha di bidang ekonomi dan bermanfaat bagi warga masyarakat. Dalam beberapa kasus program pemberdayaan di wilayah lainnya, misalnya di kawasan pesisir Pengandaran, sinergi antara dinas pemerintah daerah mulai dari perencanaan, pelaksanaan dan evaluasi menjadi salah satu faktor penting keberhasilan sebuah program pemberdayaan (Sartika, 2011 : 117). Demikian pula hasil studi yang dilakukan oleh Tahir $(2002 ; 12)$ yang melakukan studi di kawasan pesisir teluk Balikpapan dan Marliana (2013:
84) yang melakukan studi di kawasan pesisir Sampang. Kedua peneliti tersebut menyimpulkan bahwa untuk menunjang keberhasilan pembangunan kawasan pesisir, maka pemerintah daerah memasukkan kawasan tersebut dalam perencanaan Rencana Tata Ruang Wilayah Kota Balikpapan dan Kabupaten Sampang, sehingga bukan hanya dinas kelautan yang terlibat, namun juga dinas tata ruang maupun Bappeda ikut terlibat. Bentuk-bentuk sinergi dalam pengelolaan yang demikian penting untuk diaplikasikan dalam pengembangan pesisir Kebumen ke depan.

\section{SIMPULAN}

Perubahan corak pengembangan masyarakat pesisir yang mencoba mengedepankan partisipatif masih diliputi oleh persoalan corak top-down yang cukup kuat. Masalahnya, tarik ulur antara corak top-down dan bottom-up tersebut menimbulkan kurang sesuaian dengan kebutuhan grassroot. Meskipun masyarakat terlebih dahulu mendefinisikan keinginan dan kebutuhannya, namun pedoman teknis program pengembangan tetap menjadi penentu akhir. Kondisi demikian tampak dalam implementasi PKPT di belahan pesisir Kebumen tersebut. Bahkan masyarakat kurang mengerti subtansi ketangguhan yang dimaksudkan dalam program PKPT tersebut. Potret masyarakat pesisir Kebumen yang tidak semua menjadi nelayan juga menjadi persoalan dalam implementasi PKPT. Semangat awal PKPT yang partisipatif sesungguhnya sudah memberikan harapan bagi keberlanjutan program pengembangan yang tidak hanya sebagai project semata. Sayangnya ruang bottomup yang ada masih menjadi kontrol pengambil kebijakan. Kelahiran KMP sebagai pengelola PKPT di tingkat desa, di tengah keragaman berbagai kelompok masyarakat yang sudah terlebih dahulu dibentuk seperti kelompok usaha bersama, pokdakan, pohlasar justru menjadikan dominasi elit-elit lama yang berkecimpung di berbagai kelembagaan fungsional desa tersebut. Menguatkan kelompok masyarakat yang sudah ada dan berbasis keinginan masyarakat yang sesungguhnya mungkin menjadi alternatif untuk mendukung keberlangsungan program PKPT dan yang sejenisnya ke depan. Apalagi tuntutan UU No.6 Tahun 2014 untuk pengelolaan anggaran dan pembangunan desa, membutuhkan kekuatan masyarakat yang terorganisir secara kuat, khususnya dalam pengembangan BUMDes yang secara subtantif sejalan dengan exit strategy PKPT. Di atas segalanya, memperluas sifat bottom-up mungkin menjadi alternatif pencapaian tujuan program pengembangan yang berkelanjutan.

\section{UCAPAN TERIMA KASIH}

Tim peneliti mengucapkan terima kasih kepada pihak Universitas Jenderal Soedirman yang telah 
membiayai penelitian ini melalui Riset Unggulan Tahun Anggaran 2016. Ucapan terima kasih juga tim sampaikan semua pihak di lingkungan Dinas Kelautan dan Perikanan Kabupaten Kebumen, Pemerintah Desa Jogosimo, Pemerintah Desa Tegalretno, Kelompok Masyarakat Pesisir Desa Jogosimo dan Tegalretno, serta masyarakat setempat yang telah bersungguhsungguh mendukung pelaksanaan penelitian ini.

\section{DAFTAR PUSTAKA}

Aminah, Siti, 2010. Strategi Pemberdayaan Nelayan Berbasis Keunikan Agroekosistem dan Kelembagaan Lokal. Laporan Penelitian, IPB Bogor.

Afifi, Mansur. dan Latifah, Siti, 2011. Peranan Kelembagaan bagi Pengembangan Sumber Daya Non Material dalam Menunjang Pembangunan Perdesaan. Jurnal Sosiohumaniora Unpad, Vol. 13 No.3, $263-273$.

Dokumen Penilaian Ketangguhan Kawasan, 2015. Kebumen : Dinas Kelautan dan Perikanan.

Djoeffan, Sri Hidayati, 2002. Strategi Partisipasi Masyarakat dalam Perencanaan Pembangunan di Indonesia. Jurnal Mimbar Unisba, Vol. 18 No.1, 54-77.

Juniarta, Hagi Primadasa, 2013. Kajian Profil Kearifan Lokal Masyarakat Pesisir Pulau Gili Kecamatan Sumberasih Kabupaten Probolinggo. Jurnal ECSOFiM Vol. 1 No. 1, 11-25.

Marliana, Dian, 2013. Kebijakan Pengelolaan Wilayah Pesisir Berbasis Sustainable Development Di Kabupaten Sampang. JAP Jurnal Administrasi Publik Unibraw, Vol.1 No.3, 80-86.
Nikijuluw, Victor PH, 2010. Aspek Sosial Ekonomi Masyarakat Pesisir dan Strategi Pemberdayaan Mereka dalam Konteks Pengelolaan Sumber Daya Pesisir Secara Terpadu, Prosiding Pelatihan Pengelolaan Wilayah Pesisir Terpadu. repository.ipb.ac.id, 14-27.

Pedoman Teknis Pengembangan Kawasan Pesisir Tangguh 2015, 2015. Jakarta : Kementerian Kelautan dan Perikanan.

Profil Kawasan Pesisir Kebumen, 2015. Kebumen : Dinas Kelautan dan Perikanan.

Puspitaarum, Monik Ajeng, 2017. Perencanaan Pembangunan Pertanian Tanaman Pangan Kabupaten Cilacap. Jurnal Ilmiah Administrasi Publik, Vol. 3. No.1 2017, 60-70.

Sartika, Ika, 2011. Evaluasi Kebijakan Pemberdayaan Nelayan. JIANA Jurnal Ilmu Administrasi Negara, Vol. 11 No.2, 111-124.

Satries, Wahyu Ishardino, 2014. Mengukur Tingkat Partisipasi Masyarakat Kota Bekasi dalam Penyusunan APBD Melalui Pelaksanaan Musrenbang. jurnal-online ip.unikom.ac.id, Vol 2 No.1, 89-130.

Corbin, Juliet, dan Strauss, Anselm 1990. Basic of Qualitative Research: Grounded Theory Procedur And Techniques. Beverly Hills, SA, Sage Publications.

Tahir, Amirudin, 2002. Analisis Kesesuaian Lahan dan Kebijakan Pemanfaatan Ruang Kawasan Pesisir Teluk Balikpapan. Jurnal Pesisir dan Lautan, Vol. 4 No.3, 1-16. 